\title{
Pseudoachalasia as First Manifestation of a Malignancy
}

\author{
Elisabeth Fabian ${ }^{\mathrm{a}, \mathrm{b}}$ Andreas J. Eherer ${ }^{\mathrm{c}}$ Carolin Lackner $^{\mathrm{d}}$ Christian Urban $^{\mathrm{e}}$ \\ Freyja-Maria Smolle-Juettner ${ }^{f}$ Guenter J. Krejs ${ }^{c}$ \\ a Division of Gastroenterology and Hepatology, Department of Internal Medicine III, Medical University of Vienna, \\ Vienna, Austria; 'bivision of General Surgery, Department of Surgery, Medical University of Vienna, Vienna, Austria; \\ 'Division of Gastroenterology and Hepatology, Department of Internal Medicine, Medical University of Graz, Graz, \\ Austria; ${ }^{d}$ Institute of Pathology, Medical University of Graz, Graz, Austria; ${ }^{e}$ Division of Pediatric Hematology and \\ Oncology, Department of Pediatrics and Adolescent Medicine, Medical University of Graz, Graz, Austria; ${ }^{\mathrm{f} D i v i s i o n}$ of \\ Thoracic and Hyperbaric Surgery, Department of Surgery, Medical University of Graz, Graz, Austria
}

\section{Keywords}

Pseudoachalasia - Achalasia · Cardia

adenocarcinoma - Neoadjuvant chemotherapy ·

Esophageal resection - Esophagojejunostomy

\begin{abstract}
Pseudoachalasia is a condition in which symptoms, radiologic, endoscopic, and manometric findings mimick idiopathic achalasia. About $4 \%$ of patients with a typical constellation for idiopathic achalasia will turn out to have pseudoachalasia, posing a major diagnostic challenge. A large spectrum of underlying causes of pseudoachalasia has been described. However, in about $70 \%$ of affected patients, this condition is caused by a malignancy (mostly adenocarcino-
\end{abstract}

ma of the esophagogastric junction or cardia). We describe a 16-year-old high school student referred for management of achalasia who turned out to have pseudoachalasia due to adenocarcinoma of the cardia. He was cured with preoperative chemotherapy followed by radical surgery. Therapy of pseudoachalasia secondary to neoplasia is directed against the tumor or may be palliative to keep the lumen open. Other causes of pseudoachalasia include esophageal motility disturbances as a paraneoplastic phenomenon (e.g., with small cell lung cancer), post fundoplication or post bariatric surgery, in association with a thoracic aortic aneurysm, or with sarcoidosis or amyloidosis. Therapy is directed accordingly to eliminate or correct the underlying cause.

(c) 2019 S. Karger AG, Basel

\section{KARGER}

(c) 2019 S. Karger AG, Basel

E-Mail karger@karger.com

www.karger.com/ddi
Guenter J. Krejs, MD, AGAF, MWGO

Division of Gastroenterology and Hepatology

Department of Internal Medicine, Medical University of Graz

Auenbruggerplatz 15, A-8036 Graz (Austria)

E-Mail guenter.krejs@medunigraz.at 


\section{Introduction}

Idiopathic achalasia (Greek: failure to relax) is a rare primary motility disorder of the esophagus caused by the loss of nitric oxide and vasoactive intestinal polypeptide releasing inhibitory interneurons in the myenteric plexus that are involved in facilitating lower esophageal sphincter (LES) relaxation for gastric accommodation of food boluses [1-3]. This results in aperistalsis in the tubular esophagus and impaired relaxation of the LES [4]. The pathogenesis of achalasia is not yet fully understood. Basically, loss of the inhibitory innervation of the esophagus can be due to extrinsic (including central nervous lesions involving the dorsal motor nucleus or the vagal fibers) or intrinsic causes (loss of the inhibitory ganglion cells in the myenteric plexus). At different stages of achalasia, a spectrum of histopathological changes, that is, esophageal myenteric inflammation with subsequent progressive destruction of the myenteric ganglion cells and occurrence of neural fibrosis can be found [5]. It is suggested that this inflammation-associated pathophysiology is due to an autoimmune-mediated response to an unknown insult (probably an indolent viral infection) in genetically susceptible individuals $[6,7]$. This is emphasized by the finding of an inflammatory infiltrate in the myenteric plexus in patients with achalasia $[3,8]$ and a higher prevalence of circulating antimyenteric autoantibodies in those achalasia patients with class II HLA antigens $[5,9]$. Degeneration of inhibitory postganglionic neurons of the esophagus and LES due to inflammation $[10,11]$ may finally lead to impaired relaxation of the LES and hypercontractility of the distal esophagus [12]. However, associated class II HLA antigens are not found in all patients with achalasia, and some data suggest that circulatory antineuronal antibodies could also be the consequence and not the cause of the disease [5].

Typical clinical symptoms of achalasia include dysphagia for solids and liquids in up to $100 \%$ [13-15], regurgitation of undigested food (59-64\%), chest pain (17$95 \%$, predominantly observed in younger patients [16]), weight loss (30-91\%), and nocturnal cough (11-46\%) [13]. Furthermore, patients frequently report problems with belching due to alterations of the upper esophageal belch reflex [17] and hiccups, which are probably the result of esophageal distention and stimulation of afferent vagal fibers [18]. Dyspepsia and the sensation of heartburn often lead to a misdiagnosis of gastroesophageal reflux disease [19]. Thus, it is important to consider the diagnosis of achalasia in patients who do not improve on proton pump inhibitor therapy after initial diagnosis of gastroesophageal reflux disease. Although heartburn is mainly a symptom of gastroesophageal reflux, it occurs in up to $72 \%$ of patients with achalasia, even after onset of dysphagia [20]. This sensation might be due to retention of acidic or noxious food contents or to bacterial lactate production in the esophagus [21].

Pulmonary complications such as structural or functional abnormalities caused by recurrent aspiration or tracheal compression from a dilated esophagus are the most common extraesophageal manifestations of achalasia [22]. Extreme dilatation and distortion of the cervical esophagus ("bull frog neck") may further lead to tracheal obstruction and thus stridor [14]. Whether a selective defect of vagal ganglionic neurons might also affect parts of the gastrointestinal tract other than the esophagus is still unclear; associated delayed gastric emptying or gallbladder dysfunction has been described [6].

For the diagnosis of achalasia, assessment of esophageal motor function is essential; barium esophagogram and endoscopy are mandatory in addition to manometry. By definition the manometric finding of aperistalsis and incomplete LES relaxation without evidence of mechanical obstruction solidify the diagnosis of achalasia [23]. An increased basal LES pressure, an elevated baseline esophageal body pressure, and simultaneous nonpropagating contractions may also support the diagnosis [24].

Achalasia does not appear to have a specific gender or ethnic predilection. The incidence is 1 in 100,000 individuals per year with a peak between 30 and 60 years of age; the prevalence is about 10 per 100,000 population [25-27].

\section{Case Report}

A 16-year-old male high school student, a native of Austria from the state of Carinthia, presented with a 3-month history of dysphagia. He complained that swallowed solids became stuck behind his breast bone and filled up his throat. According to him, he had lost $3 \mathrm{~kg}$ of body weight, according to his mother $8 \mathrm{~kg}$. His weight on presentation was $50 \mathrm{~kg}$ with a height of $180 \mathrm{~cm}$ (BMI $15.5 \mathrm{~kg} / \mathrm{m}^{2}$, normal 18-24). Physical examination was otherwise unremarkable. He was referred to the University Medical Center of Graz and brought with him images of a barium swallow thought to show features of achalasia (Fig. 1). Esophageal manometry revealed a common channel of the body of the esophagus with loss of primary peristalsis. LES pressure was $22 \mathrm{~mm} \mathrm{Hg}$ with failure to relax completely and to decrease to fundic pressure on swallowing. Endoscopy (Fig. 2) revealed smooth mucosa in the distal esophagus with a closed cardia, which the endoscope could pass when some pressure was applied. A small erosion above the cardia was biopsied. Such erosions in achalasia may be due to food retention. Botulinum toxin was injected along the circumference of the esophagogastric junction, but did not improve his dysphagia 


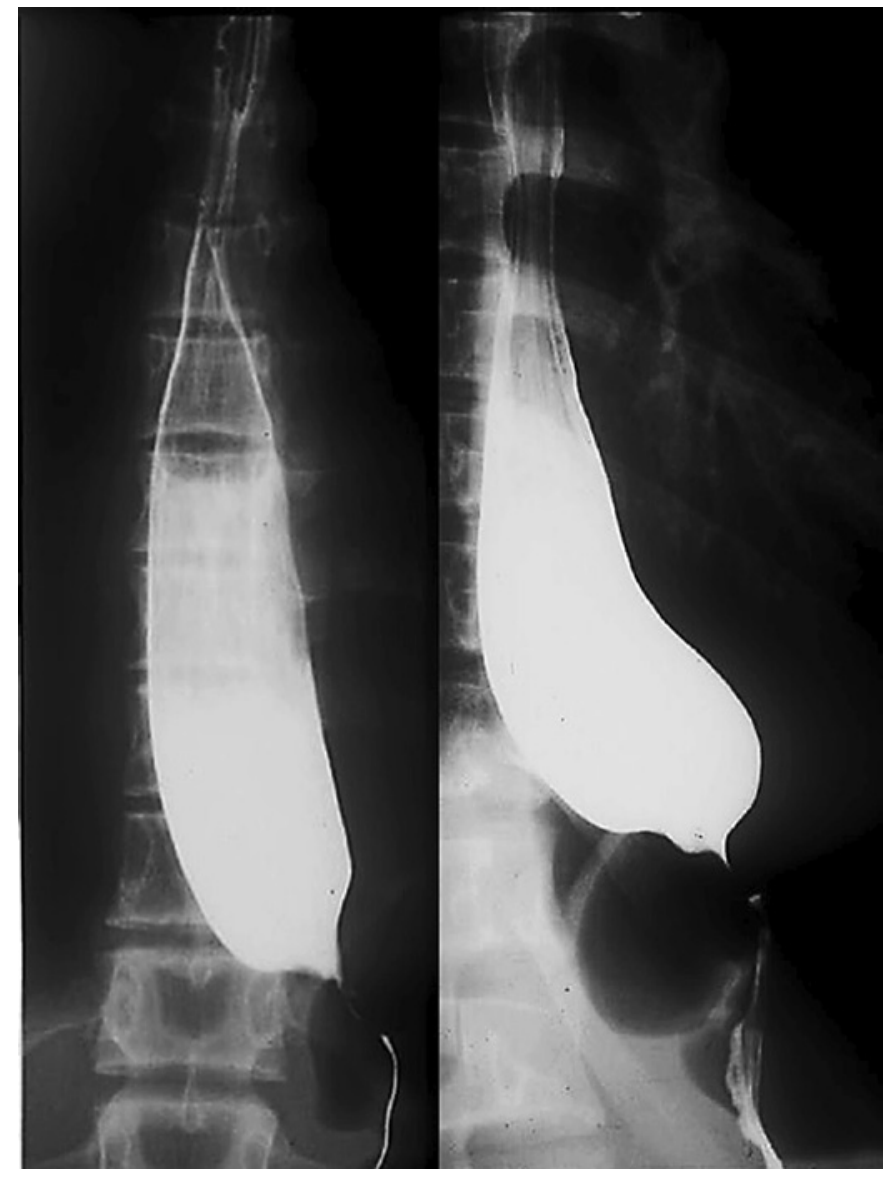

Fig. 1. Barium swallow with dilated tubular esophagus lacking peristalsis. Smooth tapering of the distal esophagus with bird's beak appearance.

thereafter. Endosonography (Fig. 3) showed what was first thought to be a thickened muscularis propria in the area of the LES in this very young man. However, the presence of an enlarged lymph node changed the interpretation and a tumor of about $4.5 \mathrm{~cm}$ in diameter was described involving all layers of the esophageal wall. The tumor was behind the left atrium and inseparable from the aorta. Computed tomography (CT) confirmed that the tumor was attached to the aorta, partially encasing it. Biopsy from the erosion showed adenocarcinoma (Fig. 4). Upon laparoscopy, a tumor encasing part of the cardia was deemed to be inoperable. There was no evidence of distant metastases. Preoperative chemotherapy (methotrexate, fluorouracil, cisplatin, doxorubicin, etoposide, and paclitaxel) [28] shrank the tumor that radical surgery could be performed 4 months later. This entailed total gastrectomy, splenectomy, lymphadenectomy, resection of the major omentum, partial pancreatectomy, and esophagectomy with esophagojejunostomy (retrosternal pull-up). Figure 5 shows the histology of the resected tumor representing well-differentiated tubular adenocarcinoma. Subsequently, the patient did well, accommodated completely to his new anatomy, and has remained free of symptoms. He gets vitamin $B_{12}$ once a month intramuscularly, and his body weight is now $59 \mathrm{~kg}$. Three times a year he is given parenteral iron replace-

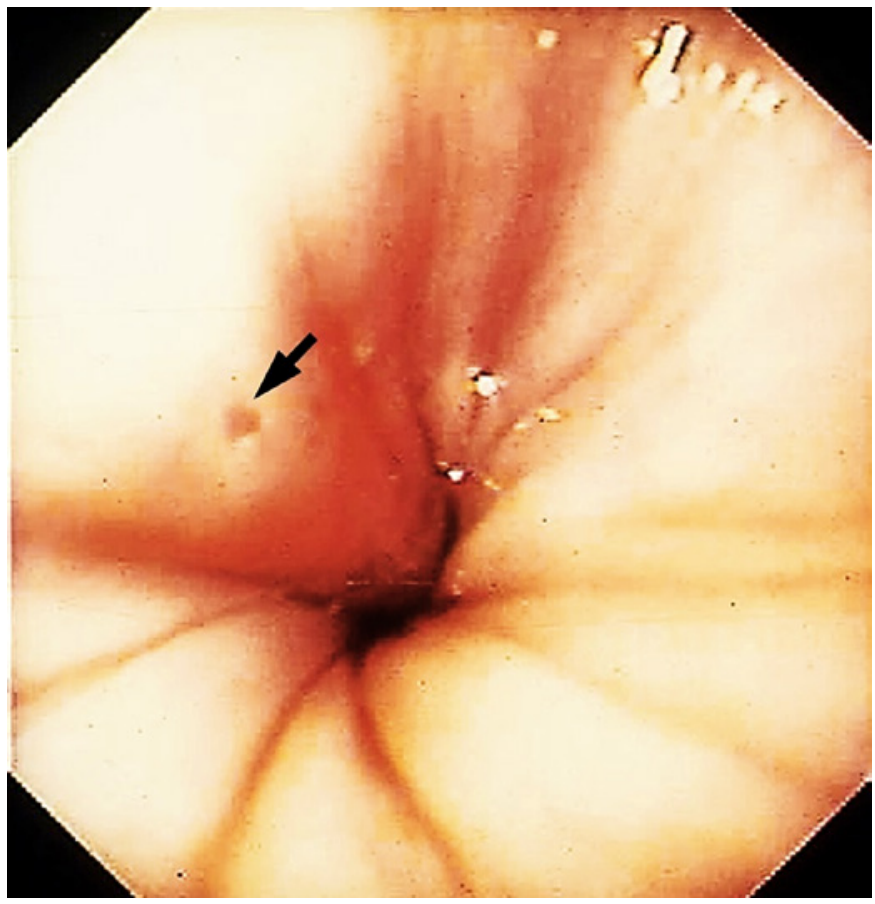

Fig. 2. Esophagoscopy: Smooth mucosa of the distal esophagus and rosette appearance of the closed cardia; 1 small erosion is visible (arrow).

ment. He will soon get a degree in physical metallurgy and has been free of tumor for a follow-up of 18 years. We have reported on this patient before and briefly after surgery $[28,29]$ but here we can add a very favorable 18 -year follow-up.

\section{Discussion}

Pseudoachalasia is a condition in which clinical and manometric features of idiopathic achalasia are mimicked by another abnormality. A large spectrum of underlying causes has been reported, including thoracic aortic aneurysm [30], rheumatoid arthritis [31], previous Nissen fundoplication [32], bariatric surgery and adjustable gastric band placement $[33,34]$, amyloidosis [35, 36], sarcoidosis [37], systemic mastocytosis [38], intestinal pseudoobstruction [39], and Chagas disease [40]. In Fabry disease, the accumulation of lysosomal $\mathrm{Gb}_{3}$ (globotriaosylceramide) leads to neuronal and vascular dysfunction that may also cause pseudoachalasia [41]. Rarely a peptic stricture can result in a reversible achalasia-like motor pattern [42]. However, in about $70 \%$ of affected patients, pseudoachalasia is caused by a primary or secondary malignancy $[43,44]$ with primary malignancy accounting for $54-70 \%$ [44-46] and secondary malignancy for $6 \%$ of cases [47]. 
Fig. 3. Endosonography of the esophagogastric junction shows (a) thickening of the MP and infiltration by a T. There is an adjacent lymphnode (top of image, arrow heads) of $1 \mathrm{~cm}$ in diameter. $\mathbf{b}$ the $T$ reaches the wall of the Ao; b of the endosonography instrument. MP, muscularis propria; $\mathrm{T}$, tumor; Ao, aorta; b, balloon.
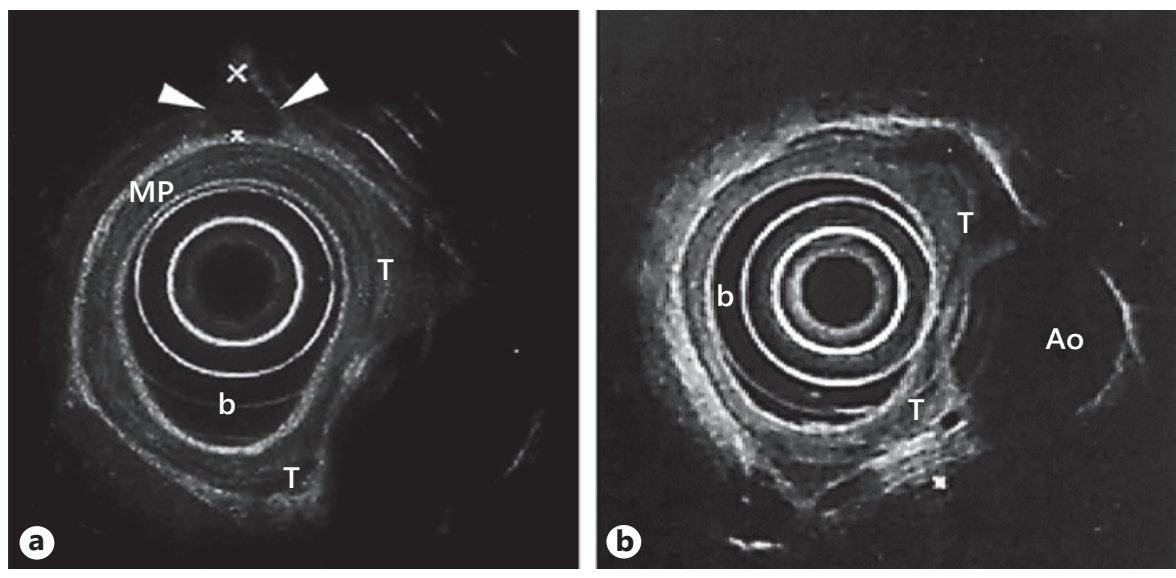
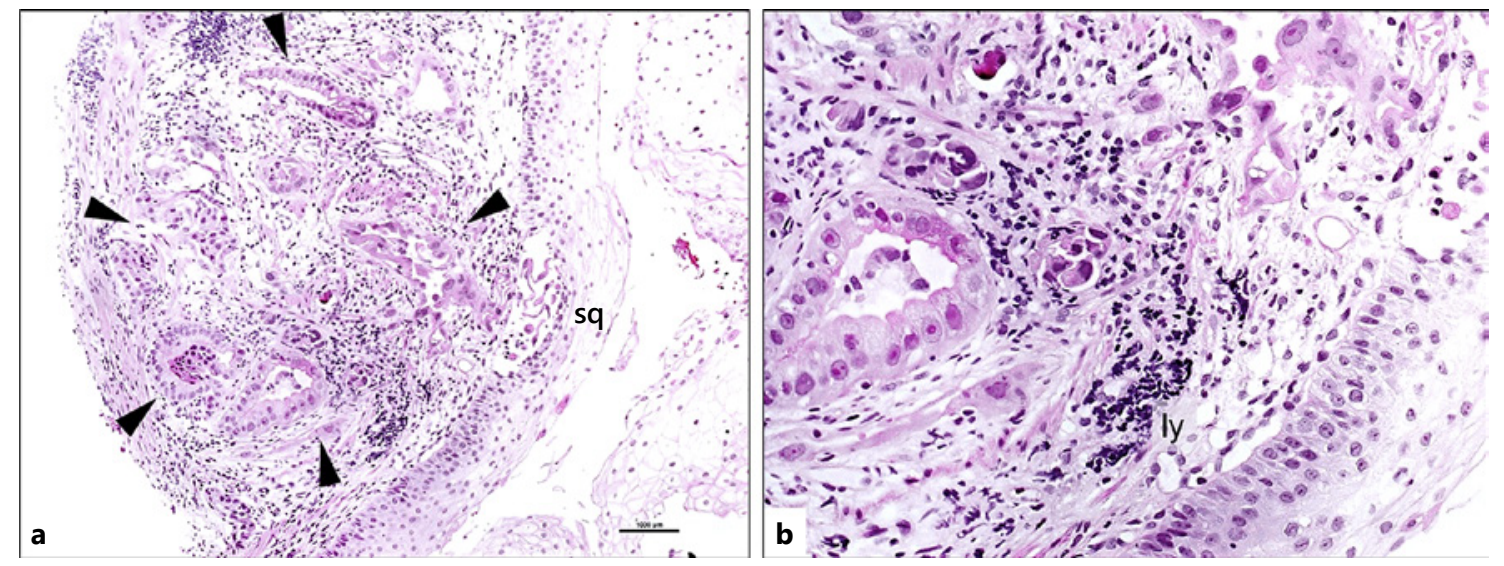

Fig. 4. Biopsy material from the esophagogastric junction. a Infiltrating tubular adenocarcinoma (area marked by arrow heads) in the submucosa covered by esophageal sq. $\mathbf{b}$ The tumor cells show enlarged polymorphic and hyperchromatic nuclei and slightly vacuolated cytoplasm. The stroma shows ly. sq, squamous epithelium; ly, lymphocytic infiltration.
Pseudoachalasia as a manifestation of a malignancy was first described by Howarth in 1919 [48] and later by Ogilvie [49]. Carcinoma of the esophagus or cardia with typical strictures of the esophagogastric junction is the tumor most likely to cause pseudoachalasia [50]. Submucosal invasion with secondary destruction of the myenteric plexus is less common [46, 51]. Invasion may have played a role in a case of urothelial carcinoma spreading to the peritoneum and pillars of the diaphragm [52] and expansion to the esophagus has also been reported in a case of cholangiocarcinoma [53]. Besides this association, pseudoachalasia has also been reported as a manifestation of such malignancies as pancreatic cancer $[31,51]$, pleural mesothelioma [54], lung cancer [55], multiple myeloma [35], and metastatic breast and cervical carcinoma [56, 57]. Paraneoplastic pseudoachalasia [58] is rare, but recently its incidence has been increasing [51]. In general, the incidence of pseudoachalasia is about $2-4 \%$ among patients with manometric findings suggesting achalasia $[45,59,60]$.

Early identification of malignancy-associated pseudoachalasia is important to avoid inappropriate treatment and delay of adequate therapy. Discriminating between idiopathic achalasia and pseudoachalasia is, however, challenging because clinical and diagnostic features, such as radiographic studies, endoscopy, and manometry, are often compatible with both diseases, as was the case in our young patient.

Since esophagogastric junction outflow obstruction is common to both achalasia and pseudoachalasia, high-resolution manometry and bolus transit measurement by impedance have not clearly advanced our ability to differentiate the 2 conditions $[27,61,62]$. In addition to the classical criteria, achalasia might present with a broad spectrum of manometric findings in individual patients. The presence 


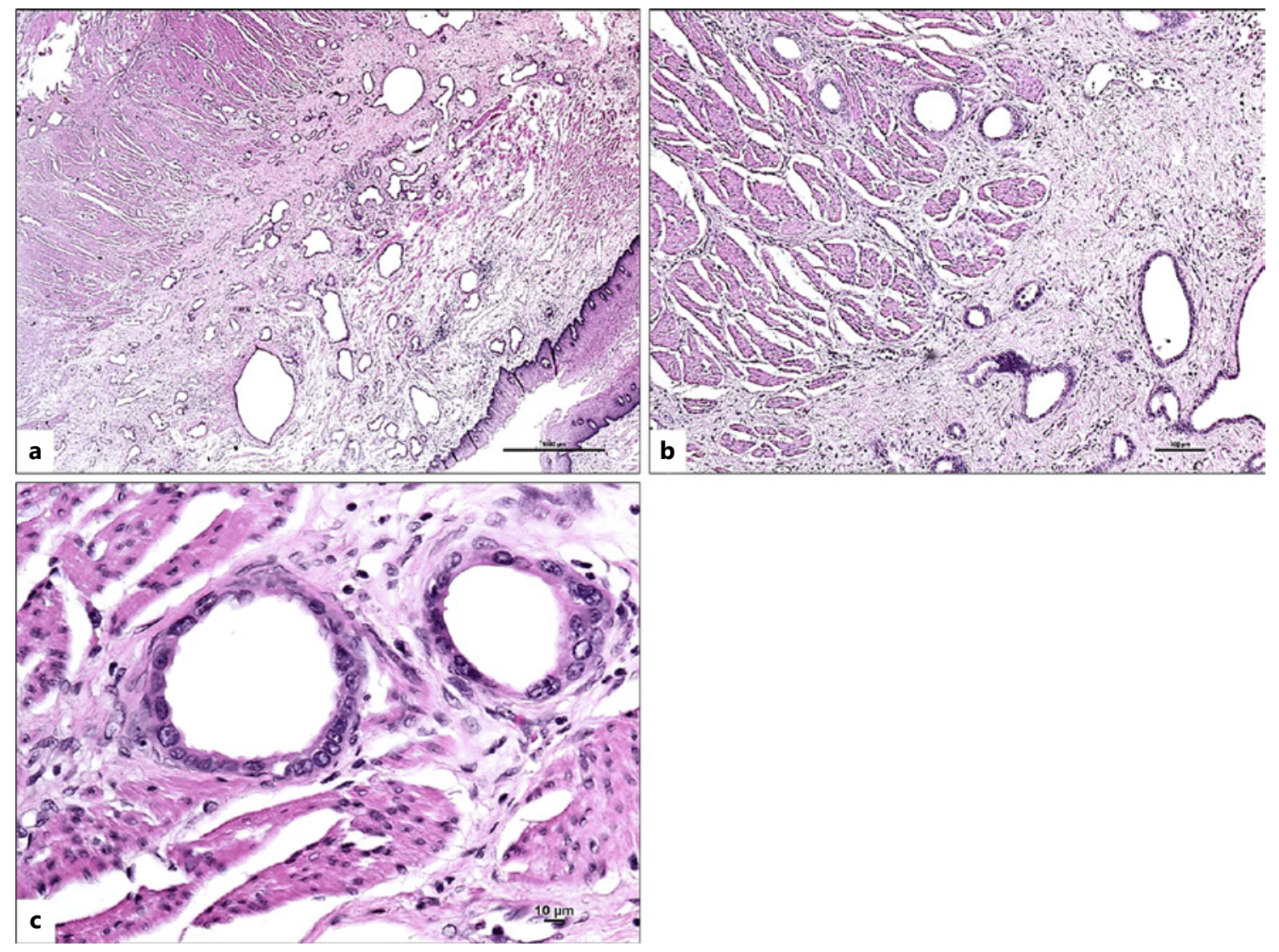

Fig. 5. Specimen from the resected esophagogastric junction with adenocarcinoma (a) infiltrating the submucosa and (b) the muscularis propria. c Tubular adenocarcinoma infiltrating smooth muscle. The polymorphic cancer cells show hyperchromatic polymorphic enlarged nuclei, enlarged nucleoli, and sparse basophilic cytoplasm. of peristalsis with some swallows, however, hints to pseudoachalasia [31]. Risk factors that suggest malignancy-associated pseudoachalasia include advanced age, short duration of symptoms, considerable weight loss, and difficulty in passing the esophagogastric junction during endoscopy. If 2 or more of these risk factors are present, further investigations are warranted to avoid missing a diagnosis of malignancy-associated pseudoachalasia [50]. The distal esophagus, the cardia, and the surrounding structures must be visualized with endosonography, CT or MRI.

Endoscopy is primarily needed to rule out a mechanical malignancy-associated obstruction. It is a reliable tool to diagnose tumors or strictures of the esophagus or cardia if the tumor crosses the submucosal layer [50]. Patients with achalasia have a normal endoscopy in $44 \%$ [13], and only $4-5 \%$ of patients with negative endoscopy and manometry positive for achalasia are diagnosed with pseudoachalasia after the performance of additional investigations [43, 44]. Although the LES pressure is elevated in achalasia, the esophagogasric junction can usually be passed meeting no more than mild resistance. A firm resistance, nodularity, ulcers, or bleeding with the passage of the endoscope raise concern for neoplastic infiltration or another cause of pseudoachalasia $[6,62]$. Esophageal biopsies are recommended in patients with dysphagia to rule out eosinophilic esophagitis. However, it should be noted that an increased number of eosinophils secondary to inflammatory processes due to stasis is frequently found in patients with achalasia $[63,64]$. Some patients with achalasia further develop candidiasis secondary to esophageal stasis. Thus, candidiasis in immunocompetent patients may also suggest an esophageal motility disorder [12].

Endosonography is recommended to differentiate between idiopathic and malignancy-associated achalasia [65]. This method can not only rule out an infiltrating tumor but may also provide supportive evidence for achalasia such as a thickened circular muscle layer $[65,66]$. However, it should be noted that a negative test does not always 
rule out pseudoachalasia [6]. Thus, in patients with negative endosonography but suspected malignancy-associated pseudoachalasia, CT or other cross-sectional imaging is mandatory. Asymmetric esophageal wall thickening, a mass around the esophagogastric junction, or mediastinal lymphadenopathy are characteristic findings associated with pseudoachalasia. Further, CT may reveal metastases or local tumors causing pseudoachalasia [67]. However, in some studies, CT detects malignancy in only $42 \%$ of patients with malignancy-associated pseudoachalasia [50].

Inhalation of amyl nitrate has also been suggested to be useful for differentiating between achalasia and pseudoachalasia, as it relaxes the LES in achalasia but not in pseudoachalasia $[45,68]$. Furthermore, technically wellperformed pneumatic dilatation or botulinum toxin injection in the area of the LES provides temporary relief of dysphagia in true achalasia but usually not in pseudoachalasia $[69,70]$. Our patient's dysphagia failed to improve following injection of botulinum toxin. In some cases with paraneoplastic pseudoachalasia, a panel of serum markers including antineuronal nuclear antibodies type 1 and antineuronal calcium channel antibodies of $\mathrm{P} / \mathrm{Q}$-type and N-type have found to be helpful $[58,71]$.

Therapy is directed against the tumor and in the best case is curative, as in the presented case. If the tumor cannot be completely removed or cured (surgery, chemotherapy, radiation), palliative measures such as stenting or even palliative resection are options. Pseudoachalasia not due to a tumor may be difficult to treat, but therapy will also be directed against the underlying cause.

\section{Conclusion}

Pseudoachalasia may be the first manifestation of a malignancy and should be suspected in patients with advanced age, short duration of symptoms, considerable weight loss, difficulty in passing the esophagogastric junction during endoscopy, and when technically wellperformed pneumatic dilatation or botulinum toxin injection in the area of the LES does not provide temporary relief of dysphagia. Discriminating between idiopathic achalasia and pseudoachalasia is challenging because clinical and diagnostic features are often compatible with both diseases. However, early identification of malignancy-associated pseudoachalasia is important to avoid inappropriate treatment and delay of adequate therapy.

\section{Acknowledgments}

The authors express their sincere gratitude to Eugenia Lamont for language editing of the manuscript.

\section{Disclosure Statement}

E.F., A.J.E., C L., C U., F.-M.S.-J., and G.J.K. state that there are no conflicts of interest.

\section{References}

1 Aggestrup S, Uddman R, Jensen SL, Sundler F, Schaffalitzky de Muckadell O, Holst JJ, Håkanson R, Ekman R, Sørensen HR: Regulatory peptides in the lower esophageal sphincter of man. Regul Pept 1985;10:167178.

2 Mearin F, Mourelle M, Guarner F, Salas A, Riveros-Moreno V, Moncada S, Malagelada JR: Patients with achalasia lack nitric oxide synthase in the gastro-oesophageal junction. Eur J Clin Invest 1993;23:724-728.

3 Clark SB, Rice TW, Tubbs RR, Richter JE, Goldblum JR: The nature of the myenteric infiltrate in achalasia: an immunohistochemical analysis. Am J Surg Pathol 2000;24:1153-1158.

4 Boeckxstaens GE: The lower esophageal sphincter. Neurogastroenterol Motil 2005; 17(suppl 1):13-21.

5 Ates F, Vaezi MF: The pathogenesis and management of achalasia: current status and future directions. Gut Liver 2015;9:449-463.
6 Eckardt AJ, Eckardt VF: Current clinical approach to achalasia. World J Gastroenterol 2009;15:3969-3975.

7 Boeckxstaens GE: Achalasia: virus-induced euthanasia of neurons? Am J Gastroenterol 2008;103:1610-1612.

8 Raymond L, Lach B, Shamji FM: Inflammatory aetiology of primary oesophageal achalasia: an immunohistochemical and ultrastructural study of Auerbach's plexus. Histopathology 1999;35:445-453.

9 Ruiz-de-León A, Mendoza J, Sevilla-Mantilla C, Fernández AM, Pérez-de-la-Serna J, Gónzalez VA, Rey E, Figueredo A, Díaz-Rubio M, De-la-Concha EG: Myenteric antiplexus antibodies and class II HLA in achalasia. Dig Dis Sci 2002;47:15-19.

10 Gockel I, Bohl JR, Eckardt VF, Junginger T: Reduction of interstitial cells of Cajal (ICC) associated with neuronal nitric oxide synthase (n-NOS) in patients with achalasia. Am J Gastroenterol 2008;103: 856-864.

11 Gockel I, Bohl JR, Doostkam S, Eckardt VF, Junginger T: Spectrum of histopathologic findings in patients with achalasia reflects different etiologies. J Gastroenterol Hepatol 2006;21:727-733.

12 Pandolfino JE, Gawron AJ: Achalasia: a systematic review. JAMA 2015;313:1841-1852.

13 Howard PJ, Maher L, Pryde A, Cameron EW, Heading RC: Five year prospective study of the incidence, clinical features, and diagnosis of achalasiainEdinburgh.Gut1992;33:1011-1015.

14 Eckardt VF: Clinical presentations and complications of achalasia. Gastrointest Endosc Clin N Am 2001;11:281-292.

15 Fisichella PM, Raz D, Palazzo F, Niponmick I, Patti MG: Clinical, radiological, and manometric profile in 145 patients with untreated achalasia. World J Surg 2008; 32 . 1974-1979. 
16 Eckardt VF, Stauf B, Bernhard G: Chest pain in achalasia: patient characteristics and clinical course. Gastroenterology 1999;116:13001304.

17 Massey BT, Hogan WJ, Dodds WJ, Dantas RO: Alteration of the upper esophageal sphincter belch reflex in patients with achalasia. Gastroenterology 1992;103:1574-1579.

18 Seeman H, Traube M: Hiccups and achalasia. Ann Intern Med 1991;115:711-712.

19 Richter JE: The diagnosis and misdiagnosis of achalasia: it does not have to be so difficult. Clin Gastroenterol Hepatol 2011;9:10101011.

20 Spechler SJ, Souza RF, Rosenberg SJ, Ruben RA, Goyal RK: Heartburn in patients with achalasia. Gut 1995;37:305-308.

21 Smart HL, Foster PN, Evans DF, Slevin B, Atkinson M: Twenty four hour oesophageal acidity in achalasia before and after pneumatic dilatation. Gut 1987;28:883-887.

22 Makharia GK, Seith A, Sharma SK, Sinha A, Goswami P, Aggarwal A, Puri K, Sreenivas V: Structural and functional abnormalities in lungs in patients with achalasia. Neurogastroenterol Motil 2009;21:603-608.

23 Spechler SJ, Castell DO: Classification of oesophageal motility abnormalities. Gut 2001; 49:145-151.

24 Pandolfino JE, Kahrilas PJ; American Gastroenterological Association: AGA technical review on the clinical use of esophageal manometry. Gastroenterology 2005;128:209-224.

25 Vaezi MF, Richter JE: Diagnosis and management of achalasia. American college of gastroenterology practice parameter committee. Am J Gastroenterol 1999;94:3406-3412.

26 Francis DL, Katzka DA: Achalasia: update on the disease and its treatment. Gastroenterology 2010;139:369-374.

27 Kahrilas PJ, Bredenoord AJ, Fox M, Gyawali CP, Roman S, Smout AJPM, Pandolfino JE; International Working Group for Disorders of Gastrointestinal Motility and Function: Expert consensus document: advances in the management of oesophageal motility disorders in the era of high-resolution manometry: a focus on achalasia syndromes. Nat Rev Gastroenterol Hepatol 2017;14:677-688.

28 Zotter H, Schwinger W, Kerbl R, Urban C, Smolle Juettner FM, Hinterleitner T: Management of a 16-year-old boy with adenocarcinoma at the esophageal gastric junction. Med Pediatr Oncol 2001,37:557.

29 Aichbichler BW, Eherer AJ, Petritsch W, Hinterleitner TA, Krejs GJ: Gastric adenocarcinoma mimicking achalasia in a 15 -year-old patient: A case report and review of the literature. J Pediatr Gastroenterol Nutr 2001;32: 103-106.

30 Beqari J, Lembo A, Critchlow J, Hamden A, Kent MS: Pseudoachalasia secondary to thoracic aortic aneurysm. Ann Thorac Surg 2017; 103:e517-e518.

31 Kim HM, Chu JM, Kim WH, Hong SP, Hahm $\mathrm{KB}$, Ko KH: Extragastroesophageal malignancy-associated secondary achalasia: a rare association of pancreatic cancer rendering alarm manifestation. Clin Endosc 2015;48: 328-331.

32 Lai CN, Krishnan K, Kim MP, Dunkin BJ, Gaur P: Pseudoachalasia presenting 20 years after Nissen fundoplication: a case report. J Cardiothorac Surg 2016;11:96.

33 Ravi K, Sweetser S, Katzka DA: Pseudoachalasia secondary to bariatric surgery. Dis Esophagus 2016;29:992-995.

34 Losh JM, Sanchez B, Waxman K: Refractory pseudoachalasia secondary to laparoscopically placed adjustable gastric band successfully treated with Heller myotomy. Surg Obes Relat Dis 2017;13:e4-e8.

35 Lazaraki G, Nakos A, Katodritou E, Pilpilidis I, Tarpagos A, Katsos I: A rare case of multiple myeloma initially presenting with pseudoachalasia. Dis Esophagus 2009;22:E21E24.

36 Benjelloun M, Peng CL, Héritier F, Roger M: [Pseudoachalasia due to amyloidosis treated by botulinum toxin]. Rev Med Interne 2007; $28: 188-190$

37 Saito S, Hosoya Y, UI T, Tanaka A, Sata N, Yasusa Y: A case of esophageal achalasia associated with sarcoidosis treated by laparoscopic surgery. J Japan Surg Assoc 2011;72: 54-57.

38 Sokol H, Georgin-Lavialle S, Grandpeix-Guyodo C, Canioni D, Barete S, Dubreuil P, Lortholary O, Beaugerie L, Hermine O: Gastrointestinal involvement and manifestations in systemic mastocytosis. Inflamm Bowel Dis 2010;16:1247-1253.

39 Schuffler MD, Pope CE 2nd: Esophageal motor dysfunction in idiopathic intestinal pseudoobstruction. Gastroenterology 1976;70(5 pt 1):677-682.

40 Bettarello A, Pinotti HW: Oesophageal involvement in chagas disease. Clin Gastroenterol 1976;5:103-117.

41 Fabian E, Schiller D, Toplak H, BrunnerKrainz M, Fazekas F, Schoefl R, Krejs GJ: Clinical-pathological conference series from the medical university of Graz : case no 153: a 55-year-old woman with atypical multiple sclerosis and irritable bowel syndrome. Wien Klin Wochenschr 2018;130:151-160.

42 Wagner A, Ravi K: Achalasia caused by a peptic stricture. Clin Gastroenterol Hepatol 2017; 15:A19-A20.

43 Campo SM, Zullo A, Scandavini CM, Frezza B, Cerro P, Balducci G: Pseudoachalasia: a peculiar case report and review of the literature. World J Gastrointest Endosc 2013;5:450-454.

44 Gockel I, Eckardt VF, Schmitt T, Junginger T: Pseudoachalasia: a case series and analysis of the literature. Scand J Gastroenterol 2005;40: 378-385.

45 Kahrilas PJ, Kishk SM, Helm JF, Dodds WJ, Harig JM, Hogan WJ: Comparison of pseudoachalasia and achalasia. Am J Med 1987;82: 439-446.

46 Liu W, Fackler W, Rice TW, Richter JE, Achkar E, Goldblum JR: The pathogenesis of pseudoachalasia: a clinicopathologic study of
13 cases of a rare entity. Am J Surg Pathol 2002;26:784-788.

47 Paulsen JM, Aragon GC, Ali MA, Brody FJ, Borum ML: Pseudoachalasia secondary to metastatic breast carcinoma. Dig Dis Sci 2010 55:1179-1181.

48 Howarth W: Discussion on dilatation of the oesophagus without anatomical stenosis. Proc R Soc Med 1919;12:64.

49 Ogilvie H: The early diagnosis of cancer of the esophagus and stomach. Br Med J 1947;2: 405-407.

50 Ponds FA, van Raath MI, Mohamed SMM, Smout AJPM, Bredenoord AJ: Diagnostic features of malignancy-associated pseudoachalasia. Aliment Pharmacol Ther 2017;45:1449-1458.

51 García-Alonso FJ, Hernández Tejero M, Castanon-Deprit A: Hepatobiliary and Pancreatic: Pseudoachalasia from pancreatic cancer. J Gastroenterol Hepatol 2015;30:1336.

52 Rodríguez-Lago I, De-la-Riva S, Súbtil JC, Lozano MD, López-Picazo JM, Muñoz-Navas M: Pseudoachalasia secondary to infiltration of the pillars of the diaphragm by an urotelial tumor: diagnostic approach with endoscopic ultrasound. Rev Esp Enferm Dig 2015;107: 121-122.

53 Kakisaka K, Endo K, Sugimoto R, Ishida K, Sugai T, Takikawa Y: Budd-Chiari syndrome and esophageal achalasia: unrecognized intrahepatic cholangiocarcinoma invading multiple organs. Intern Med 2018;57:2197-2201.

54 Branchi F, Tenca A, Bareggi C, Mensi C, Mauro A, Conte D, Penagini R: A case of pseudoachalasia hiding a malignant pleural mesothelioma. Tumori 2016;102(suppl 2).

55 Can B, Balli F, Korkmaz U, Yilmaz H, Can FI, Celebi A: Achalasia secondary to lung adenocarcinoma. Korean J Intern Med 2015;30: 250-251.

56 Lahbabi M, Ihssane M, Sidi Adil I, Dafr Allah B: Pseudoachalasia secondary to metastatic breast carcinoma mimicking radiation stenosis. Clin Res Hepatol Gastroenterol 2012;36: e117-e121.

57 Bholat OS, Haluck RS: Pseudoachalasia as a result of metastatic cervical cancer. JSLS 2001; 5:57-62.

58 Hejazi RA, Zhang D, McCallum RW: Gastroparesis, pseudoachalasia and impaired intestinal motility as paraneoplastic manifestations of small cell lung cancer. Am J Med Sci 2009;338:69-71.

59 Tracey JP, Traube M: Difficulties in the diagnosis of pseudoachalasia. Am J Gastroenterol 1994;89:2014-2018.

60 McCallum RW: Esophageal achalasia secondary to gastric carcinoma. Report of a case and a review of the literature. Am J Gastroenterol 1979;71:24-29.

61 Müller M: Impact of high-resolution manometry on achalasia diagnosis and treatment. Ann Gastroenterol 2015;28:3-9.

62 Carlson DA, Gyawali CP: Is high-resolution manometry always needed for the diagnosis of achalasia? Clin Gastroenterol Hepatol $2018,16: 480-482$ 
63 Goldblum JR, Whyte RI, Orringer MB, Appelman HD: Achalasia. A morphologic study of 42 resected specimens. Am J Surg Pathol 1994; 18:327-337.

64 Rodrigo S, Abboud G, Oh D, DeMeester SR, Hagen J, Lipham J, DeMeester TR, Chandrasoma P: High intraepithelial eosinophil counts in esophageal squamous epithelium are not specific for eosinophilic esophagitis in adults. Am J Gastroenterol 2008;103:435-442.

65 Vaezi MF, Pandolfino JE, Vela MF: ACG clinical guideline: diagnosis and management of achalasia. Am J Gastroenterol 2013;108: $1238-1249$.
66 Ziegler K, Sanft C, Friedrich M, Gregor M, Riecken EO: Endosonographic appearance of the esophagus in achalasia. Endoscopy 1990; 22:1-4.

67 Licurse MY, Levine MS, Torigian DA, Barbosa EM Jr: Utility of chest CT for differentiating primary and secondary achalasia. Clin Radiol 2014;69:1019-1026.

68 Dodds WJ, Stewart ET, Kishk SM, Kahrilas PJ, Hogan WJ: Radiologic amyl nitrite test for distinguishing pseudoachalasia from idiopathic achalasia. AJR Am J Roentgenol 1986; 146:21-23.
69 Jia Y, McCallum RW: Pseudoachalasia: still a tough clinical challenge. Am J Case Rep 2015; 16:768-773.

70 Deng B, Gao XF, Sun YY, Wang YZ, Wu DC, Xiao WM, Wu J, Ding YB: Case report: successful resection of a leiomyoma causing pseudoachalasia at the esophagogastric junction by tunnel endoscopy. BMC Gastroenterol 2016;16:24.

71 Eckmann J, Quinn K, Halland M: Paraneoplastic Pseudoachalasia: An Uncommon Presentation of Malignancy. Orlando, WCOG at ACG 2017, P259. 